УДК 181.01.-2

Жигун С. В.

кандидат філологічних наук, дочент, докторант Інституту філологіі

Київського національного університету імені Тараса Шевченка

\title{
СІЛЬСЬКИЙ ХРОНОТОП У ХУДОЖНЬОМУ СВІТІ НЕОРЕАЛІЗМУ (на матеріалі прозаїків «Ланки»)
}

У статті розглядаються такі характеристики сільського хронотопу як хліборобство, патріархальність, релігійність, природність. Дослідження виявляє дві форми реалізації сільського хронотопу у неореалістичних текстах. У першій сільський простір поєднано з історично-побутовим часом, і ией хронотоп демонструє занепад традииійних иінностей (хліборобства, патріархальності), тому позначений катастрофізмом. Другу форму сільського хронотопу творить побутовий час $і$ зосередженість на концепті природності.

Ключові слова: сільський хронотоп, хліборобство, патріархальність, релігійність, природність.

В статье рассматриваются такие характеристики сельского хронотопа как земледелие, патриархальность, религиозность, природность. Исследование устанавливает две формы реализации сельского хронотота в неореалистических текстах. В первой - сельское пространство объединено с исторически-бытовым временем и этот хронотоп демонстрирует упадок традиционных иенностей (земледелия, патриархальности), поэтому отмечен катастрофизмом. Вторую 
форму сельского хронотопа создает бытовое время и сосредоточенность на кониепте естественности.

Ключевые слова: сельский хронотоп, земледелие, патриархальность, религиозность, природность.

The article deals with such characteristics of rural chronotope as agriculture, patriarchal character, religiousness, naturalness. The research establishes two forms of rural chronotope realization in neo-realist texts. In the first one - the rural space is combined with historical and household time and this chronotope shows decline of traditional values (agriculture, patriarchal character) therefore it is marked by catastrophism. The second form of rural chronotope is created by household time and concentration on a concept of naturalness.

Keywords: rural chronotope, agriculture, patriarchal character, religiousness, naturalness

Постановка проблеми. Спроби висвітлення художнього світу певного стилю (течії, напряму) припадають на кінець ХХ століття i, зокрема, пов'язані з ім'ям Ф.Федорова, що дослідив художній світ романтизму. Відтоді ця практика отримує розвиток i втілюється у виданні Інституту світової літератури ім. М.Горького РАН «Темниця і свобода у художньому світі романтизму» (2002), що засвідчило іiі унормування. Реконструкція художнього світу передбачає опис елементів цієї естетичної структури у їх взаємодії. Актуальність дослідження полягає у потребі описати художній світ українського неореалізму, оскільки досі дослідження останнього велися переважно на матеріалі критичного дискурсу (О.Головій) чи творчій практиці окремих митців (роботи В.Панченка, О.Козій та ін.). Тому зв'язок авторського доробку із важливими науковими та практичними завданнями є очевидним.

Оскільки опис художнього світу - завдання, детальна реалізація якого годиться для низки статей, тож у пропонованій буде розглянуто один $з$ компонентів художнього світу - хронотоп, а саме його сільський варіант.

Аналіз останніх досліджень і публікацій, присвячених творчості митців 20-х років, і ланчан В.Підмогильного та Б.Антоненка-Давидовича зокрема, демонструє дисбаланс уваги на користь 
міського простору. Його висвітлюють С.Лущій, Т.Пастух, Л.Ярошевська, Н.Колошук, В.Дмитренко. Навіть ті дослідження, що заявляють аналіз взаємодії міста й села, містять останнє більшою мірою лише імпліцитно (В.Мельник, Н.Лощинська). 3 досліджень сільської тематики можна назвати статтю К.Дуба «Імператив Г.Косинки як естетичне вираження селянської ментальності» (1999), написану на матеріалі передусім імпресіоністичних творів, торкається цих питань і Н.Мафтин, М.Наєнко, О.Поляруш, Л.Кавун, однак у їхніх роботах село $є$ передусім соціо-психологічною характеристикою. Тому видається цікавим розглянути село як хронотоп, що увиразнить картину світу, відтворену неореалізмом 20 -х років.

Таким чином невирішеними раніше частинами загальної проблеми $є$ питання статусу сільського хронотопу у неореалізмі, його своєрідності проти представленого у XIX столітті. Новизна статті пов'язана як із описом елементів художнього світу, увагою до сільського хронотопу, так і з залученням творів письменників, які зазвичай досліджуються у контексті урбаністичного тексту. Зокрема, матеріалом дослідження, окрім творів Г.Косинки «Циркуль», «Політика», «Змовини» (тобто новел другого (неореалістичного) періоду творчості), стануть твори В.Підмогильного «Син», «На селі», «Іван Босий», «За день» (хоча сільський хронотоп представлено також і в повісті «Остап Шаптала», новелі «В епідемічному бараці») та Б.Антоненка-Давидовича «Крила Артема Летючого» та «Смерть». Значення дослідження пов'язане передусім 3 поглиблення знань про поетику українського неореалізму та модернізму загалом.

Виклад основного матеріалу. Українська література XIX ст., що значною мірою була рустикальною, сформувала досить стійкі уявлення про село, як систему ідей та цінностей. Їх сутність та рецепцію у літературі 20 -х років XX ст. на початку 1990 -х років досліджував В.Пахаренко, який наголошує передусім телуризм (культ землі, природи; екологічний підхід до світу, космо- і кордоцентризм), приватну власність та демократичний, родинний устрій 
суспільства [Пахаренко 1994: 3-4] як основу ціннісної системи селянина. (Ці думки перегукуються і з дослідженням Л.Горболіс, що наголошує на сакралізації землі та праці як основі сільського світогляду [Горболіс 2004], та Н.Мафтин, що вводить поняття антеїзму [Мафтин 2005]). В.Пахаренко виокремив два концептуально-ідеологічні підходи до сільської теми: романтичноморалістичний та соціально-аналітичний, яких об'єднує трактування села як моделі «досконалого, єдино іманентного для людини світу» [Пахаренко 1994: 4]. Дослідник також вважає, що характерними для теми є «розробка трьох тематичних пластів - світ села, протистояння села і міста, самоствердження інтелігенції через відновлення генетичного зв'язку з селом; творення неповторних образів селянина-правдошукача та скорботної матері; помітне превалювання романтизму; використання фольклорних зображально-виражальних засобів» [Пахаренко 1994: 5]. Аналізуючи осмислення сільської теми у 20-і роки, В.Пахаренко виявляє два вектори: соцреалістичний, що трансформує класичні традиції («Телуризм замінюється войовничим урбанізмом і техночентризмом. Уособленням гармонії, раю стає пролетарсько-більшовицьке місто, приватно-власницьке ж село - уособленням хаосу, дисгармонії, пекла» [Пахаренко 1994: 7]), та модерністський, що розвивав традиції телуризму.

Попри те, що це дослідження не втрачає свого значення й нині, сучасний розвиток знань про літературний процес 20 -х років корегує формулювання: долання телуризму у 20-х роках варто пов'язувати передусім з авангардом (а не соцреалізмом, який частково запозичив його ідеї), що ж до розвитку культу землі у модерністів, то ця теза потребує детальнішого вивіряння. Річ у тім, що до початку XX століття українські письменники (як підкреслює і В.Пахаренко) зображали тему з внутрішнього погляду, «фактично дивилися на світ очима селянина». Однак творці українського модернізму переважно сформувалися у містах і містечках, а тому часто дивилися на село ззовні (в аналізованому матеріалі це погляд 
В.Підмогильного та Б.Антоненка-Давидовича, внутрішній погляд зберігає Г.Косинка та М.Галич). Позбавлений телуризму О.Ільницький вважає, що «'селянське' (іншими словами 'хліборобське') життя ідентифікується із status qио, із такими поняттями, як нудьга, пасивність і поступливість. Ця система понять до того ж включає любов, сім'ю і шлюб» [Ільницький 1990: 52]. «Нудьгу» у цьому переліку правомірно замінити на побутовість, оскільки, саме вона спричинює постійну повторюваність подій, позбавляє різноманітності. Однак під впливом суспільно-історичних зрушень, що відбулися після 1917 року, село суттєво й разюче змінюється, а в наслідку - село позбавляється ідилічних рис, перестає бути сакральним центром життя.

Щоб розкрити сутність сільського хронотопу в обраних твоpax, необхідно його структурувати. Для багатьох 3 них справджується твердження Н.Мафтин, що «часопростір сюжету формується часто за сіткою координат: хата (родина) - праця (лан) духовність (иерква)» [Мафтин 2005: 179]. Тож головними характеристиками сільського хронотопу в цих текстах стають хліборобство, патріархальність, релігійність. Проте в деяких творах визначальним компонентом є природність. Ці групи творів розрізняються художнім часом: у перших важливим $є$ історично-побутовий час, тоді як у других - власне побутовий. Це впливає і на конфлікт: у творах першої групи представлено 1) поєднання національнополітичного конфлікту із психологічними колізіями («Мати», «Іван Босий», «Смерть»), 2) психологічні конфлікти $з$ елементами соціальних («Циркуль», «Син») та 3) соціальні («Політика», «Змовини»); а в творах другої групи конфлікти психологічні: немає героїв-антагоністів, тож немає гострої боротьби, герої протистоять загальноприйнятому і самому собі («На селі», «Крила Артема Летючого»). Таким чином у межах сільського топосу маємо два хронотопи, які розглянемо почергово.

Отже, осердям сільського хронотопу із історичним часом $є$ суспільна криза поглядів на такі важливі речі як влада, власність, 
релігія, праця тощо. Визначальним компонентом хронотопу є релігійність, яка не лише пронизує свідомість героїв (незалежно від соціального стану), але й визначає часові параметри. Адже історичний час поєднано із церковним календарем: частина подій в повісті «Остап Шаптала» відбуваються на Великдень, у «Крилах Артема Летючого» у петрівку, а у «Фавсті» та «Політиці» - на Різдво. Однак якщо у творах романтики вітаїзму такі знакові часові маркери мали символічне значення (напр. «Байгород» Ю.Яновського), то у аналізованих творах вони контрастують із зображеними подіями. Проте найважливіший прояв релігійності у сільському хронотопі - це апокаліптичні мотиви. Загальний огляд структури часу в художньому світі неореалізму демонструє, що вона переважно $\epsilon$ бінарною (минуле й теперішнє, злам між якими і визначає сюжет та конфлікт твору), однак у сільському хронотопі з'являються i візії майбутнього, та вони загалом кінцесвітні: «Висихатимуть криниці, річки й моря, никнутиме хліб по степах, $і$ люди жертимуть одне одного тим, щзо всі захотіли ласувати. Матері роздиратимуть свої діти, як вовчиці, всі багатства, на які поласились люди, їм ні на щзо не здадуться, й той рай, щуо обіцяли ӥм діти Антихриста, буде їм пеклом, прокляттям і смертю» [Підмогильний 1991:132]. Апокаліпсис мислиться селянами як кара за гріхи: грабіж під час громадянської війни; а нова влада видається їм від нечистого. У цьому контексті цікавою $є$ новела В.Підмогильного «За день», що змальовує дві події: похід протагоніста до поновленої ікони та на виступ делегата Всеукраїнського з’їзду рад. Дублювання структури оповіді й рефрен «Не руште оман...» фактично ствердили комунізм як нову релігію, і ї̈ обіияний рай є сумнівним: «нікому не урвати ланцююг людського лиха» [Підмогильний 1989:3]. Таким чином занурення людини у зло, яке змальовували неореалісти, та кінцесвітнє трактування життєвих перспектив є спадком реалізму XIX століття, осердям якого, як ствердив Л.Ушкалов, $є$ есхатологічна ідея. 
Виявом близького кінця світу стає руйнування предковічних основ: нівеляція хліборобства (через посуху чи розкуркулення) та руйнування патріархальності. Аналізовані тексти зберігають хліборобську традицію українського селянства, щоправда життєдайність землі позбувається піднесеності, символічності і в умовах голоду набуває гіркої конкретності. Хліборобство є основним і незмінним заняттям, набуваючи етичного змісту: «Діди й прадіди, думаю, хліборобили, а дочка в пани попнеться?.. Хай не иурається коло святого хліба впадати» [Косинка 1988: 213] - так коментує він «вихід» бажаного зятя з сільського середовища (той здобував фах інженера). Хліб позначається і на мисленні героїв: Андрій Романюк порівнює свою тугу із сажкою на пшениці, польські шинелі нагадують йому кольором жито, а голодному Коропу село уподібнюється до коп хліба.

Пейзажі переважно зображають степ (не дикий, а розораний), поля і землю: «Таке синє поле, аж в очах міниться. Земля лежить колотою грудою, і на пашні розколини, мов рани: нема дощу!»[ Косинка 1988: 164]. При цьому зображення переважно позбавлені ідилічності, пасторальності, вони не надихають героя, не розпружують, а нагнітають: «Навкруги - висмажені сонцем хліби, зачучверілі від спеки огудини баштанів, обпалені стовбурці проса, листаті соняхи, пожвакані сараною» [Підмогильний 1989:3]. Як влучно підмітила О.Харлан, розглядаючи один з пейзажів у новелі «Син»: «для передачі екзистенційного напруження в оповіданнях весь текст пронизано словами та образами, щуо маркують катастрофічне світосприйняття та світовідчуття персонажів: 'жовтий, мертвий, степ', 'вигорілі ниви', 'мирмаві стовбуриі занедбаного хліба', 'безкрая палюча жовтизна', 'пожежа', 'вогонь'»[Харлан 2007: 216]. Це особливо помітно у творах Г.Косинки, адже його імпресіоністичні твори часто були пленерними, і природа в них була самодостатнім світом, долучаючись до якого, людина відновлювалася. Натомість неореалістичні твори демонструють обмеженість вибору сільської природи (лише у 
«Смерті» згадується ліс, а в «Сині» - річка) опосередковано виказуючи міцний зв’язок селянина із працею. Радість від перебування на природі повноцінно звучить лише у мисливській поемі «Семен Іванович Пальоха», однак у ній герої приїздять не в село, а на полювання, тож сільський топос має незначну вагу - як оселя дивака нероби-мисливця, основне ж місце дії - плавні.

Криза патріархальності виразно постає у творах Г.Косинки «Політика» та «Змовини». Перший демонструє розпад родини не лише у сцені сутички між Мусієм Швачкою та його родичами, але й у згадках про попереднє розкуркулення (поламані тещині ребра, андріанове добро тощо) та втечу Мусія з «комуною», коли він полишив жінку й дітей на милість родичів та поталу супротивників. Тож перейнявшись більшовицькими гаслами, Мусій, як тисячі йому подібних, почали руйнувати предковічні основи свого суспільства. Порушення відвічних основ родинного життя і поваги до батьків драматизує й оповідання В.Підмогильного «Син»: у часи голоду, коли дочка жаліє хліба для матері, батько вигонить 3 дому власних дітей, і від родин лишаються самі сироти, нормальне, людяне поводження головного героя з матір'ю викликає нерозуміння оточення і недовіру.

Творам про громадянську війну та військовий комунізм притаманне також висвітлення національних питань. Село постає тереном громадянської війни й напруги в очікуванні помсти. У цьому контексті загострюються стосунки між містом і селом, оскільки перше, з погляду селян, є джерелом нав'язаної влади: звідси приїздять активісти та карателі («Іван Босий», «Смерть»). Осердям «українського націоналізму» постає село у свідомості нового комуніста Костя Горобенка: прагнучи назавжди викреслити своє минуле (участь у національно-визвольних змаганнях) з своєї біографіï, він вирушає розстрілювати заручників (заможних селян), що означає для нього стріляти в позавчорашнього самого себе. Але націю представляють не лише стомлені й пригнічені люди, якими постають заручники, але й Прокіп Конюшина («Фавст»). І справді 
символічною є його передача хліба (!) темному Конончуку, якою автор висловлював свої надії. Тож село постає середовищем, здатному сформувати й зберегти українську націю.

Сільський хронотоп із побутовим часом представлено двома творами («На селі» та «Крила Артема Летючого»). У цих творах неможливо навіть визначити, коли саме відбуваються події - до революції чи у перші іï роки? Але це й не суттєво, адже у внутрішньому світі цих оповідань існують лише приватні події 3 життя героїв. Цим творам притаманний принцип єдності людини й природи. У ньому земля набуває психологічних рис: «I була вона [земля - С.Ж.] не рахманна, як стерня восени, а збентежена. Бо навесні все порозкидається $i$ шукає собі пари» [АнтоненкоДавидович 1999: 225], а подібність чорногуза на корнета Штокке 3 часів служби Артема Летючого у драгунах наштовхує героя спробувати здолати обмеженість людської природи й полетіть. Це переконання вводить героя у конфлікт із релігійною хліборобською свідомістю його оточення: «Був дядько роботящий, землю шанував, і хоч змагали його злидні, та пращював чоловік...Був чоловік, ma збувся» [Антоненко-Давидович 1999: 227], - так характеризують селяни переміни 3 Артемом Летючим, а його загибель трактують як кару Божу.

Природність села у творах В.Підмогильного корелює із зняттям культурних заборон у стосунках, вивільненням інстинктів. Скажімо, в оповіданні «Добрий Бог» згадуються сільські розваги героїв, хоч вони й опиняються поза сюжетом, а в оповіданні «На селі» випадковий неконтрольований потяг героя (гостя 3 міста) $є$ центральною подією, яка нівелює плани героя розібратися з соціалізмом і унеможливлює подальше перебування у товаристві. На думку Г.Кудрі, «автор простежує, як впливають на підсвідомість пробуджуючи чуттевість персонажа, такі чинники, як ніч, пісня (прояв кордоцентризму) та близькість жіночого тіла» [Кудря 2001: 7], однак видається, що головним фактором ситуації стає саме топос, що підкреслює й заголовок. Тому висновок дослідника, 
що образ ночі письменник асоціативно поєднує 3 підсвідомістю, можна продовжити, додавши до цієї пари асоціацій і село. Саме у зв'язку з цим поєднанням виникають естетизовані образи поля: «Туm вночі чудово, - думав він, жуючи стиглі зерна, - вночі, коли замість розпеченого металу на небі сріблиться холодок. Тоді струнко стоять стебла та милуються зорями, котрих тепер поглинуло ненажерливе сонце. Вночі чей килим стеблів розливає пахощчі в повітрі на славу місячю, а той обсипає його діамантами... Неодмінно сюди иієї ночі з Оксаною» [Підмогильний 1991: 90]. Але ця ідилія пов'язана не з телуризмом, а з свободою інстинктів.

Чи існує зв“язок між цими двома втіленнями сільських топосів? Щоб відповісти на це питання, варто згадати дослідження М.Тарнавського, де він продемонстрував конфліктність розуму та ірраціональності у творчості В.Підмогильного, які втілюються відповідно у день, обов'язки, обмеження, матеріалізм, міське життя / ніч, свободу, чуттєвість, індивідуальність, степ, село [Тарнавський 2004:]. I хоч йдеться про оказіональну творчу практику, яку ніяким чином не можна поширити на неореалізм, оглянутий матеріал дає підстави говорити про те, що в більшості творах село $є$ ірраціональним: воно вивільняе інстинкти («Циркуль», «Політика»), актуалізує релігійні вірування («Іван Босий», «За день»), фантазію («Крила Артема Летючого») та сексуальну свободу («На селі»). Ірраціональність першого з оглянутих хронотопів втілилась в катастрофізм. Цей умонастрій втілює острах загрози важливим цінностям, однак ними у художньому світі неореалізму є не телуризм, а індивідуальна свобода, чуттєвість, підсвідомість, яким загрожує удаваний раціоналізм нової влади.

\section{БІБЛІОГРАФІЯ}

Антоненко-Давидович 1999 - Антоненко-Давидович Б. Твори : в 2т. - Т.2.

/Б.антоненко-Давидович. - Київ, 1999. - 653 с.

Горболіс 2004 - Горболіс Л. Герой у зв'язках із сакральною землею: нові аспекти прочитання української класики / Л.Горболіс // Українська мова і література в школі. - 2004. - № 3. - С. 61-66 
Ільницький 1990 - Ільницький О. Конфлікт між козацьким і селянським світоглядом у романі «Хіба ревуть воли, як ясла повні?» / О.Ільницький // Слово і час. 1990. - №4. - C.51-56

Косинка 1988 - Косинка Г. Гармонія /Г.Косинка. - К., 1988. - 605 с.

Кудря 2001 - Кудря Г. Художні пошуки Валер'яна Підмогильного: концепція людини, риси національної ментальності. Автореф. Дис... канд. філол. наук : 10.01.01 / Харк. Нац. Ун-т ім. В. Каразіна. - Харків, 2001. - 18 с.

Мафтин 2005 - Мафтин Н. Антеїзм як світоглядна основа новелістичного мислення Василя Стефаника та Григорія Косинки / Н.Мафтин // Збірник наукових праць НДІУ, Т. VI. - К., 2005. - с.176-186

Пахаренко 1994 - Пахаренко В. Ідейно-естетичні альтернативи концепції соціалістичного реалізму в українській літературі 20 -х років (на матеріалі сільської тематики): Автореф. Дис... канд. філол. наук: 10.01.02/ НАН України. Інститут літератур ім. Т.Г.Шевченка. - К., 1994. -21 с.

Підмогильний 1991 - Підмогильний В. Оповідання. Повість. Романи /

В.Підмогильний. - К., 1991.-800с.

Підмогильний 1989 - Підмогильний В. За день /В.Підмогольний // Літературна Україна. - 10 серпня 1989. - С.3

Тарнавський 2004 - Тарнавський М. Між розумом та ірраціональністю. Проза Валер'яна Підмогильного ;Пер. $з$ англ. В. Триліс /М.Тарнавський. - К., 2004. - 230с. Харлан 2007 - Харлан О. Катастрофізм текстуального простору малої прози

В.Підмогильного / О.Харлан // Мова і культура. - К., 2007. - Вип. 9. -Т.12. C. 91-97.

Стаття надійшла 1 вересня 2013 р. 